\title{
GLOSSARY OF TERMS
}

\section{Absolute accident}

An absolute accident was an accident (q.v.) that some philosophers believed could act as a subject for other accidents, in the same way as a substance normally did. Wyclif was heavily critical of philosophers and theologians who spoke of such things, and was especially cynical about claims that the consecrated host was itself an absolute accident, an assumption which itself relied on the more dubious premise (for Wyclif, at least) that the substances of the bread and wine were annihilated at the point of consecration.

\section{Absolute and ordained powers of God}

The distinction between the absolute and ordained powers of God was introduced in the twelfth century in order to negotiate questions relating to divine freedom and omnipotence. Though the distinction was formulated in a variety of subtly different ways (often with different terms for the respective powers), it was generally accepted that God's absolute power (that is, his absolute omnipotence) enabled him to do anything that did not contravene the laws of logic. In principle, he could therefore do anything that did not entail a contradiction. When he created the universe, however, God foreclosed many of the potentialities that would have been available to him in respect of his absolute power. Those that remained available to him constituted his ordained power.

In broad terms, this was the theory inherited by late fourteenthcentury scholars from the earlier Oxford luminaries John Duns Scotus, William of Ockham and Robert Holkot. It is important to stress that none of these scholars, nor indeed Wyclif and his contemporaries, considered these two powers to be distinct entities in real terms; divine power was necessarily one thing. The distinction, however, allowed scholastics to consider divine power from two different perspectives: God's power was infinite in respect of his own nature, but it necessarily operated within the laws he had himself ordained. His absolute power, many insisted, would necessarily permit him, nevertheless, to re-ordain or even suspend his own laws, should he wish. 


\section{Accident}

Accidents are properties that a thing or a person may have, but which are not part of its essence or quiddity. An accident can therefore change the formal properties of a thing (such as its colour) without changing its essence. The nine kinds of accident listed by Aristotle in Chapter 4 of the Categories are quantity, quality, relation, place, time, state (or habit), posture, action and passion. Wyclif discussed the accidents at length in On Predicamental Being, attaching primary significance to quantity (like most other scholastics), but without regarding it as an absolute accident (De Ente Praedicamentali, pp. 48-54). See also Absolute accident.

Actuality and potentiality (or potency)

See Potentiality (or potency) and actuality

\section{Agent}

In a proposition, the agent (from Latin agere, to act) is the person or creature that is responsible for the process described. In 'Wyclif wrote a sermon', the agent is Wyclif. The term was used in opposition to patient (q.v.).

\section{Analogy (adj. analogical)}

Wyclif often suggests that God may be described in a particular way analogically, but without further elaboration. What he is identifying is a form of comparison that would have been familiar to most scholastics, but which is rather alien to readers of today. Analogy represented a particular form of description that was used on the assumption that human terms could not be used of God in the same way as they were used of human beings (or of the created world). God, after all, is perfect, but human beings and the created world are not. For a medieval theologian to say that God was good, therefore, was to understand the quality of goodness in relation to God only in so far as the word could be applied or understood in relation to the created world; the sense of the adjective good in either case was therefore different but analogical. What this meant is that human goodness was properly proportionate to divine goodness in analogical terms, but nevertheless still different. Human conceptions of goodness could only ever be approximate to divine goodness, but since the two were properly similar, since humanity was created in God's image, they could be said to be properly proportionate to each other. 


\section{Antonomasia (adjective antonomastic)}

Antonomasia is the substitution of an epithet or the name of a position or office for a person's proper name, as in the king or the subtle doctor. This term is derived from the Greek anti (instead) combined with onomázein (to name).

\section{Categorematic and syncategorematic terms}

In the first chapter of On Predicamental Being, Wyclif offers a standard distinction between categorematic terms (categoremata) and syncategorematic terms (syncategoremata). The former, he argues, can stand by themselves in a proposition (either as subject or predicate), whereas the latter can be used only in combination with categorematic terms. Categorematic terms are terms that signify things or concepts, and include nouns, personal pronouns and verbs. Syncategorematic terms are predominantly grammatical words, and include conjunctions, prepositions and adverbs. Some terms, such as adjectives and demonstrative pronouns, can be used either categorematically or syncategorematically. In the proposition omnes senescent (all will grow old), for example, the adjective omnes (all) stands alone as the subject of the proposition. In the proposition homines omnes senescent (all men will grow old), by contrast, it is used in conjunction with the noun homines (men), on which it is dependent.

\section{Category}

The ten categories introduced in chapter 4 of Aristotle's Categories cover what the scholastics would classify as substances and accidents. They are substance, quantity, quality, relation, place, time, state (or habit), posture, action and passion.

\section{Consequent}

A consequent is something that occurs as a consequence of something else. The term is often used in scholastic to consider the consequence of a particular premise or assumption.

\section{Essence}

The essence of something is what makes it what it is. Hence, the essence of a stone is its stoniness, but does not include its accidental properties (colour, texture, etc.). Because of his belief in universals, Wyclif believed that the essence of a thing preceded its existence in the world. The term was normally used interchangeably with quiddity (q.v). 


\section{Evangelist}

This term is generally used in Wyclif's writings to identify the writers of the gospels, rather than preachers of Christian doctrine more generally.

\section{Extreme}

An extreme is either the subject or the predicate of a proposition.

\section{Genus (pl. genera)}

The genus (Greek génos) of a thing was listed among Aristotle's five predicables (q.v.) in book 1 of the Topics. Aristotle used genus to define the essence of a group of related things in broad terms. The genus animal thus identifies, and is thus predicable of, a wide range of living organisms, including humans and cats. These latter organisms, though sharing the same genus, however, belong to different species (q.v.). As a philosophical realist, Wyclif believed that genera and species represented more than predicables, which acted only as taxonomic labels or concepts. For him, they were real universal categories, which metaphysically defined their particulars (rather than simply describing them).

\section{Indulgence}

An indulgence was remission of punishment in purgatory for a particular sin; a plenary indulgence offered remission of penalties for all sins in purgatory at the point of death. Indulgences were granted by the church on condition that the individual concerned was contrite and had already confessed (and had hence obtained remission from guilt). They were widely abused in medieval England and in Europe.

\section{Mercy}

Medieval theologians recognised two basic kinds of mercy: corporal mercy and spiritual mercy. An act of corporal mercy would include any merciful action that brings physical benefits to the recipient, such as feeding the hungry or tending to the sick. Such mercy, though itself realised in a physical action of some king, could be motivated by spiritual concerns (such as pity for an individual). An act of spiritual mercy is a merciful action that has spiritual benefits, such as praying for someone in need or forgiving an offence.

Ordained power of God

See Absolute and ordained powers of God. 


\section{Paralogism}

An argument that was based on false premises, and which was therefore necessarily erroneous, was identified by medieval logicians as a paralogism. Wyclif uses the term frequently, identifying many of his opponents' arguments as paralogisms.

\section{Patient}

In medieval logic, a patient is a creature or thing that is subjected to a process (from Latin patior, to suffer/undergo). Hence, in the sentence 'John Wyclif wrote a sermon', the sermon that is mentioned is the patient. The term was normally used in opposition to agent (q.v.). The agent here is John Wyclif.

\section{Potentiality (or potency) and actuality}

The distinction between dýnamis (potentiality) and enteléxeia or enérgeia (actuality) was described in detail by Aristotle in book theta of the Metaphysics, which was known in Latin from the thirteenth century. Aristotle argued that there were two ways in which potentiality could exist: it could either inhere in a subject, as when something covered in oil has the potential to catch fire, or in an agent, as when architectural potentiality resides in a builder (1046a). Though the basic principles of this distinction were accepted by most medieval philosophers, there was periodic disagreement about whether a given thing should be regarded as potential or actual.

A related Aristotelian concept was that of disposition. This was an acquired state that presupposed a certain skill or quality, and hence certain potentialities. The Aristotelian virtue of courage, for example, would have been classified as a disposition, but did not represent an actuality until it was realised in courageous acts of some kind.

\section{Predicable}

The 'predicables' introduced by Aristotle in the first book of the Topics (chapters 4, 5 and 8) identify the ways in which a predicate can relate to its subject in a proposition. They do this by broadly classifying the kinds of things that may be predicated of that subject. These are the five Aristotelian predicables: definition (or species), property, genus, difference and accident.

\section{Predicament (adjective predicamental)}

The term predicament was an alternative name for an Aristotelian 
category. Wyclif's On Predicamental Being was an introductory treatise on the ten Aristotelian categories.

\section{Predication}

Wyclif uses this term in an extended sense to cover two different processes. The first is linguistic predication (the normal focus of logic in medieval universities), in which a predicable (q.v.) is be predicated of a subject in a proposition. The second is real predication, in which a genus and a species are metaphysically predicated of a real subject. An example of linguistic predication would be 'James is human', in which the species human is predicated of the subject James. Real predication is the corresponding process in the world. Hence, the individual James has the species human, a universal, predicated of him by virtue of the fact that he is human. As the subject of a real proposition, James (and all other members of the human species) is connected to this universal by his essence (the real correlate of the linguistic copula, to be).

\section{Prime matter}

Prime matter is an Aristotelian concept, and represents matter in its purest state. Aquinas, commenting on Aristotle, suggested that it must therefore be regarded as pure potentiality (q.v.). When matter assumed a particular form (such as that of a tree or a stone), it was therefore no longer primary in this original sense. The addition of form could hence be seen to have entailed a necessary deficit, which some scholastics interpreted as a kind of annihilation.

\section{Quality (adjective qualitative)}

A quality is an attribute of a thing, such as its colour or texture.

\section{Quantity}

Wyclif preserves the Aristotelian distinction between continuous and discrete quantities.

Continuous quantity: a continuous quantity is one that is not bound by extremes.

Discrete quantity: a discrete quantity is one that is finite, and hence bound by extremes.

\section{Quiddity (adjective quidditative)}

The quiddity of something is literally its 'whatness' (from Lat. quid, what). In scholasticism, this is normally a thing's essence (q.v.). 


\section{Secret prayer (or Secret)}

A prayer made by the celebrant at the liturgy of the Eucharist. The prayers were not secrets in the modern sense, but were so called because they were said by the priest inwardly and silently.

\section{Sects}

Wyclif speaks frequently of the damage to the church caused by the four sects, by which he means not the four orders of friars but the secular clergy, monks, canons and friars. See the discussion in the Introduction, under Wyclif's Life.

\section{Species}

Species was the Latin term for the first of the five Aristotelian predicables (q.v.), which was used to identify the essence of a thing in a specific way. Aristotle had himself used the word hóros (definition) in his description of this predicable in Book 4 of the Topics. The definition or species of a group of things was arrived at by considering their genus (q.v.) and the properties that differentiated them from other members of that genus. These differentiating properties occupied a separate predicable category called diáphora in Aristotle (differentia in Latin). It was in the Latin translation of Porphyry's Isagoge produced by Boethius in the sixth century (which gradually displaced the earlier Latin translation of Marius Victorinus), that definition was first labelled species.

Wyclif regarded species, like genera, as more than linguistic or logical predicables. For him, they were real universals that were metaphysically predicated of all of the individuals belonging to a given species. Hence, all humans, by virtue of being such animals, have human predicated of them in real terms.

\section{Subject}

In a logical context, the subject of a proposition is the word or phrase of which something is said or predicated (such as John in 'John is human'). For Wyclif and philosophers of the realist tradition such as Walter Burley, however, a subject could also be a thing in the world, which could be part of a real proposition. In the case of any given man, Wyclif would have said that such an individual had the species human predicated of him by virtue of the fact that he was a human being. His essence would have been seen to connect the subject John to the predicate human (and hence to act as the real correlate of the linguistic copula to be). 


\section{Substance}

Substance (from Latin substantia) was the first of Aristotle's categories (which was known by a variety of terms in Greek). Aristotle drew a distinction between primary substances, which were individual things, and secondary substances, which were species or genera (qq.v.). Only primary substances could stand by themselves. At the end of the first chapter of On Predicamental Being, a treatise dedicated to the Aristotelian categories, Wyclif tacitly acknowledges this point when he argues that all of the nine 'accidental predicates' can be 'traced back' to a substance, which is necessary to sustain them ( $D e$ Ente Praedicamentali, p. 14). In his later writings, he defends this traditional position vehemently, rejecting the popular philosophical claim that the accidents of the Eucharist could in some way be sustained by another, 'absolute' accident. It is worth pointing out here that there was never complete consensus among medieval philosophers about what a substance was.

\section{Supposit}

A supposit is the thing that a term stands for in a proposition. In 'men are human' the supposit of the term men would be all men; in 'some men are greedy', it would be only a portion of the adult male population.

\section{Supposition}

The logic of supposition was used to describe the behaviour of linguistic terms in a proposition. It characterised precisely what a given term referred to, or 'supposited' for. There were three kinds of 'proper' (that is, literal) supposition: material, simple and personal. The last of these is arguably the most straightforward, and occurs when a term supposits literally for something in the world. Hence, in the proposition 'men are human', the term men supposits for all men in the world. Simple supposition occurs when a term supposits for a genus or a species, rather than for a thing or things, as in the proposition 'animal is a universal'. Material supposition occurs when a term supposits for a term in a proposition, as in 'man is a word'. Supposition was not strictly the same as signification. In the first example, the word men signifies in a conventional way before it is used in a proposition, by virtue of belonging to the English lexicon. It supposits for all men, however, when it is used in the proposition 'men are human'. It clearly supposits in a different way in the proposition 'some men are greedy'. Improper supposition occurrs when a term is used figuratively in a proposition, as in 'Peter is a monster'. The distinction between signification and 
supposition was drawn in a variety of ways, and was not always clearly observed. In his Logic, for example, Wyclif regards supposition as a particular kind of signification, defining it as the signification of one categorematic term, which is one extreme of a proposition, in relation to the other extreme' (De Logica, vol. 1, p. 39).

\section{Syllogism}

Aristotle's theory of the syllogism was central to the development of logic is the later medieval period. It was developed in the Prior Analytics, available in Latin translation from the twelfth century. Here, the syllogism was represented as a form of induction (24b17), which contained three categorical propositions. Two of these were premises (the major and the minor premise, respectively) and the third was a conclusion that was inferred from them. Syllogisms therefore took the following form:

All A are B (the major premise)

Some $\mathrm{A}$ are $\mathrm{C}$ (the minor premise)

Some B are C (conclusion)

$\mathrm{A}, \mathrm{B}$ and $\mathrm{C}$ are variables here, for which terms may be substituted. Hence, A could be humans, whilst B could be bipeds and C philosophers. The conclusion here would therefore be that some bipeds are philosophers. The form of the propositions in a syllogism therefore contains a subject, a copula (the verb to $b e$ ) and a predicate. Most propositions also contained quantifiers, such as the ones used here (all and some). Propositions could be either affirmative or negative (the latter taking the form Some A are not $C$ ), and could be universal (like the major premise here), particular (like the minor premise here), or indefinite, in cases when no quantifier was used. An example of Wyclif's use of the syllogism can be found in his discussion of the Eucharist (20), in which he argues that Christ's body is certainly eaten by the faithful (the major premise), but it is not eaten by them substantially (the minor premise). He concludes from this that Christ is not present in the Eucharist substantially, but sacramentally.

\section{Trope (adjective tropical)}

Wyclif uses this term generically to describe figurative language of any kind. Its adjectival form should not be confused with tropological, which has a more specific meaning in medieval exegesis. 


\section{Viator}

A viator is literally a wayfarer (from Latin via, way, journey), but in medieval Christian literature it is typically a spiritual pilgrim on earth, whose desired destination is the heavenly city.

\section{Worldly goods}

I have used this phrase to translate the Latin temporales, which Wyclif generally used to identify worldly things. As a truly apostolic individual, he generally regarded such possessions as worthless encumbrances to a truly spiritual life. 